\title{
Histopathological evaluation of formalin toxicity in Arapaima gigas (Arapaimidae), the giant fish from Amazon ${ }^{1}$
}

\author{
Sanny M. Andrade-Porto 2,5 , Cleverson A. Ramos ${ }^{3}$, Rosemary Roque ${ }^{4}$, \\ Elizabeth G. Affonso ${ }^{4}$, José F.M. Barcellos ${ }^{3}$, Marieta N. Queiroz ${ }^{5}$, Cleusa S.O. Araújo ${ }^{6}$ \\ and Marcos Tavares-Dias ${ }^{7 *}$
}

\begin{abstract}
Andrade-Porto S.M., Ramos C.A., Roque R., Affonso E.G., Barcellos J.F.M., Queiroz M.N., Araújo C.S.O. \& Tavares-Dias M. 2018. Histopathological evaluation of formalin toxicity in Arapaima gigas (Arapaimidae), the giant fish from Amazon. Pesquisa Veterinária Brasileira 38(6):1015-1025. Embrapa Amapá, Rodovia Juscelino Kubitschek Km 5, Macapá, AP 68903-419, Brazil.E-mail: marcos.tavares@embrapa.br

This study aimed to determine the lethal concentration and the structural and ultra-structural effects caused by the formalin exposure on juveniles of Arapaima gigas. Ninety fish $(60.1 \pm 2.5 \mathrm{~g}$ and $20.2 \pm 0.9 \mathrm{~cm})$ were exposed to $0,22,44,66,88$ and $110 \mathrm{mg} \mathrm{L}^{-1}$ in order to determine the lethal concentration $\left(\mathrm{LC}_{50-96 \mathrm{~h}}\right.$ ) that was $36.4 \mathrm{mg} \mathrm{L}^{-1}$ of formalin. Sublethal effects were evaluated using histopathological analysis on the gills and assessment of behavioral alterations and clinical signs. The $\mathrm{LC}_{50}$ of formalin for 24,48 and $72 \mathrm{~h}$ was $88.3,64.7$ and $56.8 \mathrm{mg} \mathrm{L}^{-1}$ respectively. Clinical signs and behavioral changes were found: erratic swimming, lethargy, crowding on the water surface, loss of hydrodynamic equilibrium, spasms and agonistic confrontation, which were observed only at 88 and $110 \mathrm{mg} \mathrm{L}^{-1}$. The histological alteration index (HAI) showed that 66,88 and $100 \mathrm{mg} \mathrm{L}^{-1}$ presented significant difference $(\mathrm{p}<0.05)$ in relation to unexposed fish, indicating that moderate damage to the gills of fish exposed to formalin had occurred. The mean values of alteration (MVA) for $22,44,66,88$ and $110 \mathrm{mg} \mathrm{L}^{-1}$ were $1.14,1.29,1.51,1.53$ and 1.60 respectively, and differences in this index were only observed with $110 \mathrm{mgL}^{-1}$ of formalin. It is therefore possible to conclude that sublethal concentrations of formalin $\left(22.0 \mathrm{mg} \mathrm{L}^{-1}\right)$ did not compromise the health of juveniles of A. gigas. Finally, concentrations greater than to $\mathrm{LC}_{50-96 \mathrm{~h}}$ may be carefully used for short-term exposure, since the MVA for all concentrations tested only indicated localized lesions that did not compromise gills functionality of exposed fish.
\end{abstract}

INDEX TERMS: Formalin, toxicity, Arapaima gigas, Arapaimidae, freshwater fish, pirarucu, treatment, histopathology, toxicoses.

\footnotetext{
${ }^{1}$ Received on November 1, 2016.

Accepted for publication on May 16, 2017.

${ }^{2}$ Curso de Pesca, Departamento de Recursos Pesqueiros, Universidade Federal do Amazonas (UFAM), Av. General Rodrigo Otávio 6200, Coroado I, Manaus, AM 69067-005, Brazil.

${ }^{3}$ Departamento de Morfologia, Instituto de Ciências Biológicas, Universidade Federal do Amazonas (UFAM), Av. General Rodrigo Otávio 6200, Coroado I, Manaus, AM 69067-005.

${ }^{4}$ Instituto Nacional de Pesquisas da Amazônia (INPA), Av. André Araújo 2936, Petrópolis, Manaus, AM 69067-375.

${ }^{5}$ Programa de Pós-Graduação em Aquicultura, Universidade Nilton Lins, Av. Prof. Nilton Lins 3259, Flores, Manaus, AM 69058-580.

${ }^{6}$ Universidade do Estado do Amazonas (UEA), Av. Djalma Batista 3578, Manaus, AM 69050-030.

${ }^{7}$ Embrapa Amapá, Rodovia Juscelino Kubitschek Km 5, Macapá, AP 68903-419, Brazil. *Corresponding author: marcos.tavares@embrapa.br
}

RESUMO.- [Avaliação histopatológica da toxicidade da formalina em Arapaima gigas (Arapaimidae), o peixe gigante da Amazônia.] 0 presente estudo teve como objetivo determinar a concentração letal e efeitos estruturais e ultraestruturais causados pela exposição a formalina em juvenis de Arapaima gigas. Noventa peixes $(60,1 \pm 2,5 \mathrm{~g}$ e $20,2 \pm 0,9 \mathrm{~cm}$ ) foram expostos a $0,22,44,66,88$ e $110 \mathrm{mg} \mathrm{L}^{-1}$, para determinar a concentração letal $\left(\mathrm{CL}_{50-96 \mathrm{~h}}\right)$ de formalina que foi $36,4 \mathrm{mg} \mathrm{L}^{-1}$. Os efeitos subletais foram avaliados por análises histopatológicas das brânquias e avaliação das alterações comportamentais e sinais clínicos. $\mathrm{A} \mathrm{CL}_{50}$ de formalina para 24, 48 e 72horas foi de 88,3, 64,7 e 56,8; respectivamente. Sinais clínicos e alterações comportamentais encontradas foram: natação errática, letargia, aglomeração de peixes 
na superfície da água, perda de equilíbrio hidrodinâmico, espasmos e confronto agonísticos, observados apenas nas concentrações de 88 e 110 $\mathrm{mg} \mathrm{L}^{-1}$. O índice de alteração histológica (IAH) mostrou que as concentrações de 66, 88 e $100 \mathrm{mg} \mathrm{L}^{-1}$ apresentaram diferenças significativas $(\mathrm{p}<0,05)$ em relação aos controles, indicando a ocorrência de danos moderados nas brânquias dos peixes expostos a formalina. Os valores médios de alteração (VMA) para as concentrações 22, 44, 66, 88 e 110 $\mathrm{mg} \mathrm{L}^{-1}$ foram 1,14, 1,29, 1,51, 1,53 e 1,60; respectivamente, e as diferenças na composição desse índice foram observados apenas na exposição com $110 \mathrm{mg} \mathrm{L}^{-1} \mathrm{de}$ formalina. Foi possível concluir que concentrações subletais de formalina (22,0 $\left.\mathrm{mg} \mathrm{L}^{-1}\right)$ não comprometem a saúde de juvenis de A. gigas. Concentrações de formalina acima da $\mathrm{CL}_{50-96 \mathrm{~h}}$ podem ser usadas cuidadosamente para banho de curto tempo, uma vez que o VMA para todas as concentrações testadas indicou apenas lesões localizadas que não comprometem a funcionalidade das brânquias dos peixes expostos.

TERMOS DE INDEXAÇÃO: Formalina, Arapaima gigas, Arapaimidae, peixe de água doce, pirarucu, tratamento, histopatologia, toxicoses.

\section{INTRODUCTION}

In Brazil, the production of Arapaima gigas Schinz, 1822 commonly known as pirarucu has been intensified over the last few years, despite great challenges in consolidating the production chain. Diseases caused by ectoparasites are one of the biggest concerns, due to the low survival rates of these fish, especially during the initial stages of life (fry and juveniles) when rearing this species. Among these problems related to intensive production of A. gigas are the high rates of infestation mainly due to monogeneans Dawestrema cycloancistrioides and Dawestrema cycloancistrium, and trichodinids Trichodina heterodentata and Trichodina fariai (Delgado et al. 2007, Araújo et al. 2009, Marinho et al. 2013). These ectoparasites have been responsible for epizootic outbreaks that have caused economic losses to aquaculture of $A$. gigas.

Several chemotherapeutic products have been used to control ectoparasites in fish from aquaculture industry worldwide, and formalin is one of these (Cruz et al. 2005, Yao et al. 2011, Pahor-Filho et al. 2012, Santos et al. 2012, Ayuba et al. 2013). Fish farming use formalin for treating of ectoparasites in A. gigas; however, no study has yet been conducted to determine efficacy of this treatment and lethal concentration. In aquaculture, use of formalin in therapeutic baths is permitted in several countries, because it is considered to be a safe antiparasitic substance for use on fish destined for human consumption (Schlotfeld 1993, Fajer-Ávila et al. 2003, Farmer et al. 2013, FDA 2014). However, little information exists on the species-specific safety or efficacy of formalin treatments on Brazilian fish species, but this product is widely accepted as having efficacy (Farmer et al. 2013, Leal et al. 2017). The control of diseases is quite complex and depends upon the interplay of diagnosis, preventive measures and treatment. Thus, the correct diagnosis of diseases is a critical step in any disease control program. Therefore, in the process of disease control is possible eliminating the parasites only when the cause is correctly identified. Although therapeutics have the health benefit for fish, they might cause adverse effects. High concentrations of formalin may be toxic to fish, causing damage the gill epithelium, alterations in mucous cells and die of the exposed animals (Perera \& Pathiratne 2005, Santos et al. 2012, Leal et al. 2017). In addition, use of formalin to eliminate pathogenic agents may be responsible for negative effects on water quality of tanks (Leal et al. 2017).

Fish gills is one key organ for the action of chemical products such as formalin, because these are the first to be affected by exposure. Thus, histological evaluation of the gills can be considered a sensitive tool for detecting the effects of exposure to this product in fish (Santos et al. 2012). Therefore, studies are needed in order to understand the toxicity of formalin for A. gigas, to avoid administration of concentrations that are too high or too low. Moreover, other parameters need to be determined, such as the efficacy of this chemotherapeutic product, survival rate (lethal concentration), histopathological damages and behavioral alterations among exposed fish (Santos et al. 2012, Ayuba et al. 2013). Gills are the first to react to unfavorable environment conditions because this organ perform vital functions such as respiration, osmoregulation and excretion (Poleksic \& Mitrovic-Tutundzic 1994). The tolerance to chemicals can vary depending on the species and the treatment conditions, once the recommended concentrations and treatments for this therapeutic product are near the lethal level for some cultured fish species (Fajer-Ávila et al. 2003, Leal et al. 2017). The aim of this study was investigate the effects structural and ultra-structural of toxicity of the formalin for A. gigas.

\section{MATERIALS AND METHODS}

Obtainment and fish acclimatization. Juveniles of Arapaima gigas $(47.57 \pm 13.9 \mathrm{~g}$ and $17.45 \pm 1.8 \mathrm{~cm})$ were obtained from a commercial fish farm in the state of Amazonas, northern Brazil. The fish apparently healthy were transported to the Applied Zoology and Ichthyoparasitology Laboratory of the Nilton Lins University, Manaus, AM (Brazil), and were acclimatized for 10 days in 500L tanks with constant aeration and water exchange. During this period, the fish were fed until reaching apparent satiety, three times a day, using commercial extruded feed for carnivorous fish with $45 \%$ crude protein.

Determination of the lethal concentration $\left(\mathrm{LC}_{50-96 \mathrm{~h}}\right)$ of formalin. Initially, the fish were subjected to $24 \mathrm{~h}$ of food deprivation before beginning the experiments, to enable emptying of the gastrointestinal tract. The lethal concentration of formalin for A. gigas was determined by using acute toxicity test over a $96 \mathrm{~h}$ exposure period. The concentrations used had been previously determined through preliminary tolerance tests, in which the values chosen for the acute toxicity test corresponded to the lowest test concentration (110 $\mathrm{mg} \mathrm{L}^{-1}$ ) able to cause $100 \%$ lethality, and the highest test concentration $\left(22 \mathrm{mg} \mathrm{L}^{-1}\right)$ that did not cause lethality $(0 \%)$ among the fish. The concentrations were prepared from $37 \%$ formaldehyde (Sigma-Aldrich ${ }^{\circledR}$ ).

To determine the lethal concentration $\left(\mathrm{LC}_{50-96 \mathrm{~h}}\right)$, the experimental design comprised an entirely randomized block using five concentrations of formalin: $22,44,66$, 88 and $110 \mathrm{mg} \mathrm{L}^{-1}$, and a control $\left(0 \mathrm{mg} \mathrm{L}^{-1}\right)$, with three repetitions each. The exposures were administered out in $120 \mathrm{~L}$ aquariums, 90 fish were divided in 6 treatments with 3 replicates each and 5 fish by replicate. The distribution of the fish and the treatments in the aquariums were performed randomly, in a static system, with a 12-h photoperiod and constant aeration for complete homogenization of the product. Lethality throughout the assay was recorded after $24,48,72$ and $96 \mathrm{~h}$.

The tolerance of the fish to formalin was observed by descriptive qualitative and quantitative analysis over the period of $96 \mathrm{~h}$. To assess the death of each fish, the following criteria were considered: absence of opercula movement and reaction to any external stimulus. When death was confirmed, the fish were weighed, measured and numbered. The $\mathrm{LC}_{50}$ was estimated using the Trimmed Spearman-Karber method (Hamilton et al. 1977). The degree of toxicity of the product was 
estimated through a qualitative description, in accordance with the methodology of Zucker (1985).

Behavioral evaluation and analysis of the clinical signs. To evaluate the behavior of the animals, descriptive qualitative analysis was performed based on the following criteria: erratic swimming, lethargy, concentration at the surface, loss of balance, spasms and agonistic confrontations (Andrade et al. 2005), after adaptation. Moreover, anatomopathological analysis was applied in order to observe the external surface of the fish.

Water quality. Water quality was monitored throughout the acclimatization period (baseline) and experimental period. The following physical and chemical water variables were determined: dissolved oxygen, temperature and electric conductivity using digital multiparameter (YSI-85/10, USA); and pH using digital pHmeter (YSI-60/10, USA). The concentrations of total ammonia $\left(\mathrm{NH}_{3}+\mathrm{NH}_{4}^{+}\right)$ $\left(\mathrm{mgL}^{-1}\right)$, nitrate $\left(\mathrm{NO}_{3}\right)\left(\mathrm{mg} \mathrm{L}^{-1}\right)$ and nitrite $\left(\mathrm{NO}_{2}^{-}\right)\left(\mathrm{mg} \mathrm{L}^{-1}\right)$ were assessed through the colorimetric method, as described by Verdouw et al. (1978) and Boyd \& Tucker (1992), respectively, and the total alkalinity was evaluated through titration (Boyd \& Tucker 1992).

Procedures for collection and histopathological analysis of the gills. Among fish submitted to the acute toxicity test, the gills of 6 fish of each treatment randomly collected were remove, and fixed in $10 \%$ buffered formalin (phosphate) for histopathological analysis in historesin (Technovit $7100^{\mathrm{TM}}$ resin kit) (Hossler 1980). The second gill arch was chosen, from which the bone tissue was removed, the gill filaments were selected and embedded in historesin, in a sagittal position, to obtain sections that showed the afferent/efferent longitudinal axis of the gill filament and the lamellae in a perpendicular position. The samples were gradually dehydrated in alcohol (50-100\%), such that they were immersed in each concentration of the sequence for $30 \mathrm{~min}$. The pre-infiltration, infiltration and polymerization procedures were carried out following the recommended protocol for the Technovit $7100^{\mathrm{TM}}$ resin kit.

The polymerized samples were removed from the histological molds and were then attached to wooden blocks measuring approximately $3 \times 4 \mathrm{~cm}$, with the aid of Araldite ${ }^{\circledR}$ glue. The blocks were trimmed and placed in a Leica RM 2125 RT microtome to be cut into sections of $3 \mu \mathrm{m}$ in thickness, in the sagittal orientation in relation to the gill filaments. The slices were placed in a water bath, mounted on histological slides and dried on a plate heated to $37^{\circ} \mathrm{C}$ for approximately $1 \mathrm{~h}$. Staining was performed using the basic fuchsine and toluidine blue technique (Kiernan 1999). The material was analyzed and images from 20 random fields were recorded with the material in a sagittal position, viewed with the aid of an Olympus BX41 microscope coupled to a camera and connected to a computer.

All histopathological alterations on the gills of A. gigas specimens that underwent acute toxicity tests for $96 \mathrm{~h}$ were investigated. The histopathological alterations were evaluated by descriptive and qualitative analyses, using the mean assessment value (MAV) as described by Schwaiger et al. (1997) and calculating the histological alteration index (HAI), as described by Poleksic \& Mitrovic-Tutundzic (1994).

Scanning electron microscopy (SEM) on the gills. The second gill arch was also analyzed through SEM to observe possible gill alterations due to formalin. The samples were fixed in $1.5 \%$ glutaraldehyde buffer and dehydrated in an increasing series of alcohol exchanges, from 50 to $100 \%$, for 10 min per exchange, and performing the last one twice. The samples were then placed in metal baskets and were transferred to the critical point in a CPD 030 chamber. Approximately $50 \mathrm{~mL}$ of absolute ethanol was added until it covered the basket. Once the chamber had been isolated, liquid $\mathrm{CO}_{2}$ was injected and several substitutions were performed until the ethanol had been completely removed. The dry sample was removed from the critical point and mounted using double-sided tape on a metallic stub support to begin the metallization process with gold using a vacuum
Sputter SCD 050 BAL-TEC device. This procedure sought to increase the conductivity of the surface of the sample through a fine layer (20-30nm) of gold (Silveira 1998).The samples were observed and photographed using a scanning electron microscope (LEO 435VP) and the images were stored in a digital file.

Statistical analyses. All the data were initially assessed with regard to the assumptions of normal distribution and homoscedasticity, using the Shapiro-Wilk and Bartlett tests, respectively. The physical and chemical variables of the water during the experiment were assessed through analysis of variance (one-way-ANOVA), followed by Tukey's test to compare means. To observe the effect of formalin on the histopathological indexes (HAI and MAV) of the gills, the Kruskal-Wallis test was used, followed by Dunn's test (Zar 2010). The behavioral evaluation and the analysis on the clinical signs of the fish that were exposed to different formalin concentrations were evaluated through the chi-square test $\left(\chi^{2}\right)$. Linear regression was used to calculate the determination coefficient $\mathrm{R}^{2}$ and the equation of the line $(\mathrm{y}=\mathrm{a}+\mathrm{bx})$ that describes $\mathrm{LC}_{50-96 \mathrm{~h}}$ for formalin $(\mathrm{p}<0.05)$.

Ethical in animal experimentation. This study was developed in accordance with the principals upheld by the Brazilian College of Animal Experimentation (Cobea) and approved by the Nilton Lins University Ethical Committee on Animal Research under the Protocol No 001/2012.

\section{RESULTS}

The physical and chemical variables in the water of the aquaria did not present differences among the groups with different concentrations of formalin during the $96 \mathrm{~h}$ of exposure (Table 1 ).

Over the $96 \mathrm{~h}$ of the experiment, there was no mortality among the unexposed fish. However, 100\% mortality was observed at the highest concentrations tested (Table 2).

The $\mathrm{LC}_{50}{ }_{96 \mathrm{~h}}$ of formalin for Arapaima gigas was of $36.4 \mathrm{mg} \mathrm{L}^{-1}$ and the linear equation that represents the curve of the concentration-response relationship with formalin during the 96h of exposure of $A$. gigas (Fig.1). The lowest 95\% confidence interval values were observed during the $96 \mathrm{~h}$ period (Fig.2).

Fish exposed to the highest concentrations ( 88 and $110 \mathrm{mg} \mathrm{L}^{-1}$ ) of formalin presented behavioral alterations such as erratic swimming, lethargy, concentration at the water surface of tanks, loss of hydrodynamic balance, spasms, agonistic confrontation; after $13 \mathrm{~h}$ of exposure. Behavioral changes were not observed among the fish exposed to the other concentrations over the 96-h period of exposure (Table 3 ). Clinical signs relating to the external anatomical characteristics of the fish were only observed among those exposed to 88 and $110 \mathrm{mg} \mathrm{L}^{-1}$ of formalin (Table 4).

Histopathological alterations were observed in the gills of the fish exposed to different concentrations of formalin, classified only as stages I and II in comparison with the exposed fish (Table 5 and Fig.3).

The HAI calculation presented a significant difference at the concentrations of 66,88 and $110 \mathrm{mg} \mathrm{L}^{-1}$, in comparison with the controls, thus indicating that severe modification to the gill tissue had occurred (Fig.4). The mean assessment value (MAV) showed differences in the fish exposed to different concentrations of formalin, thus indicating that the tissue presented the stages of both stage 1 (absence of tissue alteration) and stage 2 (occurrence of lesions located separately), as demonstrated in Figure5.

Scanning electron microscopy (SEM) showed that the gills of the control fish had a normal appearance, with filaments positioned parallel along the gill arch, defined lamellae and well organized epithelial surface. Moreover, SEM also confirmed the structural alterations in the gills of 
Table 1. Physical and chemical parameters of water quality during the $96 \mathrm{~h}$ exposure of juveniles of Arapaima gigas to different concentrations of formalin. Values are expressed as mean \pm standard deviation

\begin{tabular}{|c|c|c|c|c|c|c|}
\hline \multicolumn{7}{|c|}{ Formalin concentrations $\left(\mathrm{mg} \mathrm{L}^{-1}\right)$} \\
\hline Parameters & 0 & 22 & 44 & 66 & 88 & 110 \\
\hline DO & $7.0 \pm 0.3^{\mathrm{a}}$ & $6.8 \pm 0.3^{\mathrm{a}}$ & $6.9 \pm 0.4^{\mathrm{a}}$ & $6.9 \pm 0.4^{\mathrm{a}}$ & $7.1 \pm 0.1^{\mathrm{a}}$ & $7.2 \pm 0.1^{\mathrm{a}}$ \\
\hline Temp & $25.8 \pm 0.4^{\mathrm{a}}$ & $25.1 \pm 0.3^{a}$ & $25.0 \pm 0.3^{\mathrm{a}}$ & $25.5 \pm 0.2^{\mathrm{a}}$ & $25.7 \pm 0.5^{\mathrm{a}}$ & $25.3 \pm 0.4^{\mathrm{a}}$ \\
\hline $\mathrm{pH}$ & $6.2 \pm 0.2^{\mathrm{a}}$ & $6.1 \pm 0.6_{a}$ & $6.2 \pm 0.4^{\mathrm{a}}$ & $5.8 \pm 0.9^{a}$ & $5.8 \pm 0.0^{\mathrm{a}}$ & $6.2 \pm 0.0^{\mathrm{a}}$ \\
\hline $\mathrm{EC}$ & $21.7 \pm 1.7^{\mathrm{a}}$ & $22.2 \pm 2.9^{\mathrm{a}}$ & $22.7 \pm 3.7^{\mathrm{a}}$ & $23.2 \pm 3.3^{\mathrm{a}}$ & $23.5 \pm 1.7^{\mathrm{a}}$ & $23.9 \pm 2.4^{\mathrm{a}}$ \\
\hline TA & $1.2 \pm 0.9^{\mathrm{a}}$ & $1.3 \pm 0.7^{\mathrm{a}}$ & $1.3 \pm 0.8^{\mathrm{a}}$ & $1.3 \pm 0.7^{\mathrm{a}}$ & $1.4 \pm 0.8^{\mathrm{a}}$ & $1.5 \pm 0.03^{\mathrm{a}}$ \\
\hline $\mathrm{NO}_{2}$ & $0.005 \pm 0.0004^{\mathrm{a}}$ & $0.005 \pm 0.0008^{\mathrm{a}}$ & $0.005 \pm 0.0^{\mathrm{a}}$ & $0.06 \pm 0.0^{\mathrm{a}}$ & $0.005 \pm 0.0^{\mathrm{a}}$ & $0.005 \pm 0.0^{\mathrm{a}}$ \\
\hline $\mathrm{NO}_{3}$ & $0.05 \pm 0.0^{\mathrm{a}}$ & $0.05 \pm 0.0^{\mathrm{a}}$ & $0.05 \pm 0.0^{\mathrm{a}}$ & $0.05 \pm 0.0^{\mathrm{a}}$ & $0.05 \pm 0.0^{\mathrm{a}}$ & $0.05 \pm 0.0^{\mathrm{a}}$ \\
\hline Alkal & $11.2 \pm 4.8^{\mathrm{a}}$ & $10.4 \pm 5.8^{\mathrm{a}}$ & $11.1 \pm 4.6^{\mathrm{a}}$ & $10.1 \pm 1.2^{\mathrm{a}}$ & $11.3 \pm 0.0^{\mathrm{a}}$ & $11.6 \pm 0.0^{\mathrm{a}}$ \\
\hline
\end{tabular}

DO = dissolved oxygen $\left(\mathrm{mgL}^{-1}\right), \mathrm{Temp}=$ temperature $\left({ }^{\circ} \mathrm{C}\right), \mathrm{pH}=$ hydrogen potential, $\mathrm{EC}=$ electrical conductivity $(\mu \mathrm{S} / \mathrm{cm}), \mathrm{TA}=$ total ammonia $\left(\mathrm{mgL}^{-1}\right)$, $\mathrm{NO}_{2}=$ nitrite $\left(\mathrm{mgL}^{-1}\right), \mathrm{NO}_{3}=$ nitrate $\left(\mathrm{mgL}^{-1}\right)$, Alkal = total alkalinity $\left(\mathrm{CaCO}_{3} \mathrm{mgL}^{-1}\right)$; Different letters in the same line indicate significant difference by Tukey's test $(\mathrm{p}<0.05)$.

Table 2. Mortality (\%) of Arapaima gigas exposed to different concentrations of formalin during $96 \mathrm{~h}$ of exposure

\begin{tabular}{ccccc}
\hline \multirow{2}{*}{$\begin{array}{c}\text { Concentration } \\
\left(\mathrm{mg} \mathrm{L}^{-1}\right)\end{array}$} & 24 & 48 & 72 & 96 \\
\cline { 2 - 5 } & 0 & 0 & 0 & 0 \\
22 & 0 & 0 & 0 & 6.6 \\
44 & 0 & 20.0 & 20.0 & 26.6 \\
66 & 6.6 & 40.0 & 53.4 & - \\
88 & 33.4 & 66.6 & - & - \\
110 & 100 & - & - & -
\end{tabular}

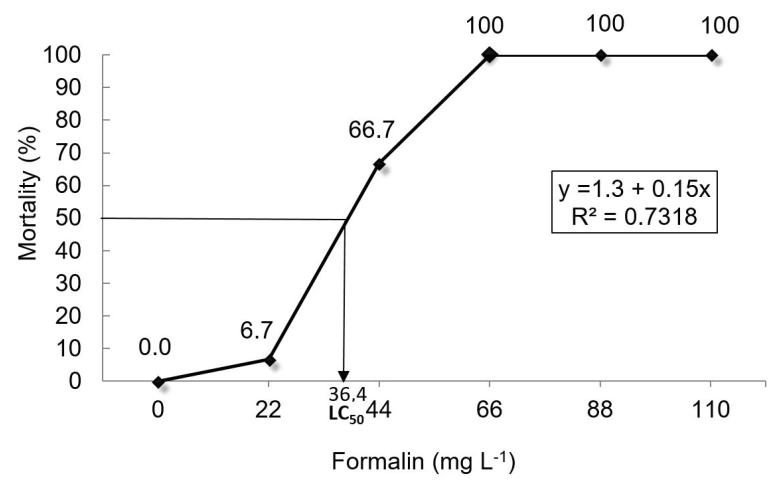

Fig.1. Concentration-response relationship curve of formalin during 96h exposure of Arapaima gigas.

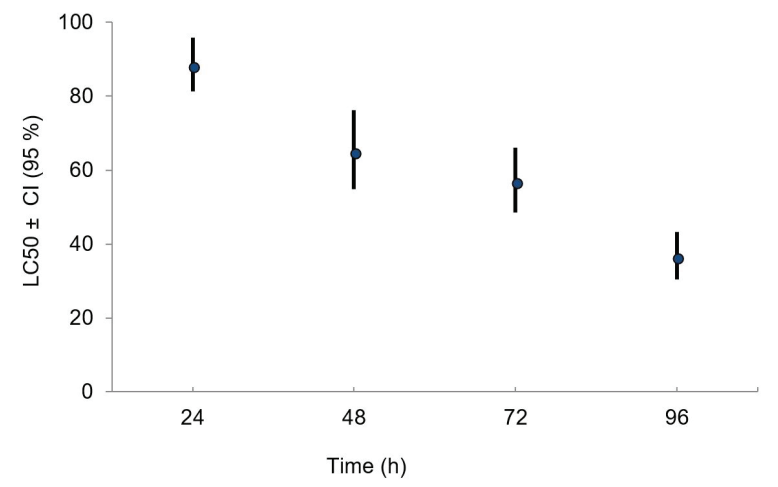

Fig.2. Lethal concentration $\left(\mathrm{LC}_{50}\right)$ of formalin for Arapaima gigas exposed to different concentrations during exposure periods of 24, 48, 72 and 96 hours.
Table 3. Behavioral alterations of Arapaima gigas during the acute toxicity test with formalin for $96 \mathrm{~h}$

\begin{tabular}{|c|c|c|c|c|c|c|}
\hline \multirow{2}{*}{ Behavioral alterations } & \multicolumn{6}{|c|}{ Formalin concentrations $\left(\mathrm{mg} \mathrm{L}^{-1}\right)$} \\
\hline & 0 & 22 & 44 & 66 & 88 & 110 \\
\hline Erratic swimming & $0^{\mathrm{a}}$ & $0^{\mathrm{a}}$ & $0^{\mathrm{a}}$ & $0^{\mathrm{a}}$ & $4 \pm^{b}$ & $13 \pm 1^{b}$ \\
\hline Lethargy & $0^{\mathrm{a}}$ & $0^{\mathrm{a}}$ & $0^{\mathrm{a}}$ & $0^{\mathrm{a}}$ & $1 \pm^{\mathrm{a}}$ & $10 \pm 2^{\mathrm{b}}$ \\
\hline $\begin{array}{l}\text { Concentration at the water } \\
\text { surface }\end{array}$ & $0^{\mathrm{a}}$ & $0^{\mathrm{a}}$ & $0^{\mathrm{a}}$ & $0^{\mathrm{a}}$ & $0 \pm 0^{\mathrm{a}}$ & $12 \pm 1^{b}$ \\
\hline $\begin{array}{l}\text { Loss of hydrodynamic } \\
\text { balance }\end{array}$ & $0^{\mathrm{a}}$ & $0^{\mathrm{a}}$ & $0^{\mathrm{a}}$ & $0^{\mathrm{a}}$ & $4 \pm^{\mathrm{a}}$ & $14 \pm 1^{b}$ \\
\hline Spasms & $0^{\mathrm{a}}$ & $0^{\mathrm{a}}$ & $0^{\mathrm{a}}$ & $0^{\mathrm{a}}$ & $0 \pm 0^{\mathrm{a}}$ & $8 \pm 2^{b}$ \\
\hline Agonistic confrontation & $0^{\mathrm{a}}$ & $0^{\mathrm{a}}$ & $0^{\mathrm{a}}$ & $0^{\mathrm{a}}$ & $0 \pm 0^{\mathrm{a}}$ & $8 \pm 2^{b}$ \\
\hline
\end{tabular}

Table 4. Clinical signs observed among Arapaima gigas during the acute toxicity test with formalin ( $\mathrm{LC}_{50-96 \mathrm{~h}}$ )

\begin{tabular}{lcccccc}
\hline \multirow{2}{*}{ Clinical signs } & \multicolumn{5}{c}{ Formalin concentrations $\left(\mathrm{mg} \mathrm{L}^{-1}\right)$} \\
\cline { 2 - 7 } & 0 & 22 & 44 & 66 & 88 & 110 \\
\hline Corneal opacity & $0^{\mathrm{a}}$ & $0^{\mathrm{a}}$ & $0^{\mathrm{a}}$ & $0^{\mathrm{a}}$ & $1 \pm 0^{\mathrm{a}}$ & $6 \pm 1^{\mathrm{b}}$ \\
Opaque gill & $0^{\mathrm{a}}$ & $0^{\mathrm{a}}$ & $0^{\mathrm{a}}$ & $0^{\mathrm{a}}$ & $2 \pm^{\mathrm{a}}$ & $12 \pm 2^{\mathrm{b}}$ \\
Hyperemia with hemorrhage & $0^{\mathrm{a}}$ & $0^{\mathrm{a}}$ & $0^{\mathrm{a}}$ & $0^{\mathrm{a}}$ & $0 \pm^{\mathrm{a}}$ & $2 \pm 0^{\mathrm{a}}$ \\
in the caudal peduncle & & & & & & \\
Friable gill & $0^{\mathrm{a}}$ & $0^{\mathrm{a}}$ & $0^{\mathrm{a}}$ & $0^{\mathrm{a}}$ & $0 \pm^{\mathrm{a}}$ & $12 \pm 2^{\mathrm{b}}$ \\
Excess mucous on the skin & $0^{\mathrm{a}}$ & $0^{\mathrm{a}}$ & $0^{\mathrm{a}}$ & $0^{\mathrm{a}}$ & $3 \pm^{\mathrm{a}}$ & $15 \pm 1^{\mathrm{b}}$
\end{tabular}
and gill

Different letters in the same line indicate significant difference $(p<0.05)$ by $\chi^{2}$ test.

the $A$. gigas specimens exposed to different concentrations of formalin (Fig.6A,B). At the concentration of $66 \mathrm{mg} \mathrm{L}^{-1}$, the gill filaments presented fewer evident lamellae (Fig.6C). Orifices in mitochondria-rich cells (MRC) and mucous cells (MC) were reported occurring at lower intensity in the filaments exposed to lower concentrations (22 $\mathrm{mg} \mathrm{L}^{-1}$ ) of formalin (Fig.6D). At the concentrations of 88 and $110 \mathrm{mg} \mathrm{L}^{-1}$, high proliferation of MRCs and MCs was observed (Fig.6E,F). Increased mucus secretion was observed beginning at the concentration of $66 \mathrm{mg} \mathrm{L}^{-1}$, while epithelium dislocation and hemorrhage were reported only at concentrations of 88 and $110 \mathrm{mg} \mathrm{L}^{-1}$ (Fig.7A-F).

\section{DISCUSSION}

Arapaima gigas exposed to different concentrations of formalin, the physical and chemical characteristics of the water did not change, as also reported in other studies (Burka et al. 1997, Fajer-Ávila et al. 2003, Pahor-Filho et al. 2012). Such parameters 
Table 5. Frequency of histopathological alterations (according to Poleksic \& Mitrovic-Tutundzic 1994 method) on the gills of Arapaima gigas $96 \mathrm{~h}$ after exposure to different concentrations of formalin

\begin{tabular}{|c|c|c|c|c|c|c|c|}
\hline \multirow{2}{*}{ Alteration } & \multicolumn{7}{|c|}{ Formalin concentrations $\left(\mathrm{mg} \mathrm{L}^{-1}\right)$} \\
\hline & Stage & 0 & 22 & 44 & 66 & 88 & 110 \\
\hline Lamellar epithelium hypertrophy & I & 0 & 0 & 0 & 0 & + & + \\
\hline Lamellar epithelium hyperplasia & I & 0 & 0 & $0+$ & + & ++ & +++ \\
\hline Proliferation of mucus cells & I & 0 & $0+$ & + & ++ & +++ & +++ \\
\hline Proliferation of mitochondria-rich cells (MRCs) & I & 0 & $0+$ & + & ++ & +++ & +++ \\
\hline Constriction of the system of pillar cells & I & 0 & 0 & 0 & 0 & 0 & $0+$ \\
\hline Partial fusion of the lamellae & I & 0 & 0 & 0 & + & + & ++ \\
\hline Total fusion of several lamellae & I & 0 & 0 & 0 & ++ & ++ & +++ \\
\hline Dilation of the marginal channel & I & 0 & 0 & 0 & + & + & ++ \\
\hline Mucus secretion & I & 0 & 0 & 0 & $0+$ & $0+$ & + \\
\hline Epithelial detachment & I & 0 & 0 & 0 & $0+$ & + & + \\
\hline Edema & I & 0 & 0 & 0 & + & ++ & ++ \\
\hline Capillary constriction & I & 0 & 0 & 0 & $0+$ & + & ++ \\
\hline Lamellar aneurism & II & 0 & 0 & 0 & $0+$ & + & ++ \\
\hline Epithelial rupture (hemorrhage) & II & 0 & 0 & 0 & + & + & ++ \\
\hline
\end{tabular}

0 = absent, $0+$ = rarely present, + infrequent, ++ frequent, +++ very frequent.

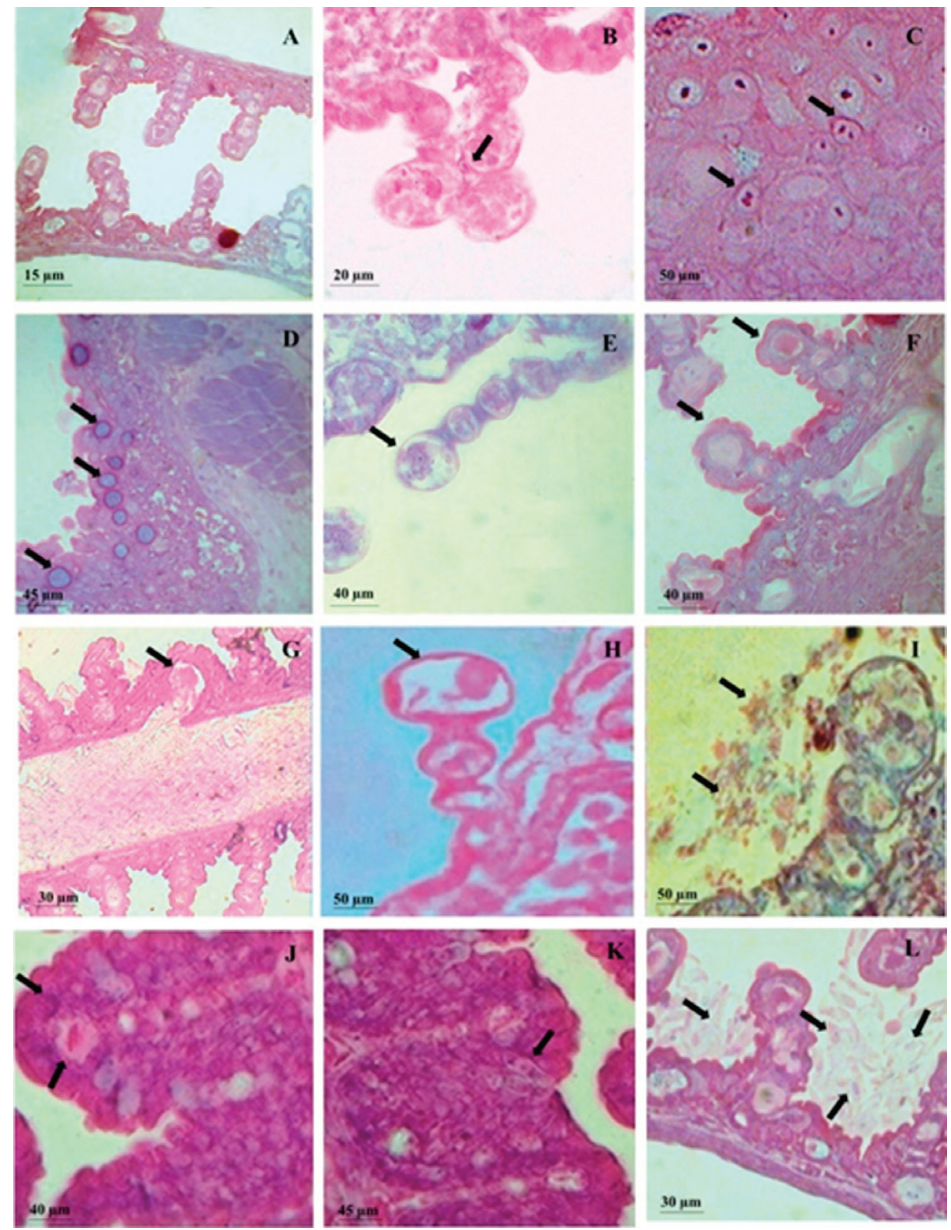

Fig.3. Histopathological alterations on the gills of Arapaima gigas exposed to different concentrations of formalin. (A) Gill filaments of unexposed fish. (B) Lamellar aneurism (tip of the arrow) in exposed fish to $110 \mathrm{mg} \mathrm{L}^{-1}$ of formalin. (C) Proliferation of mitochondria-rich cells (MRCs) in exposed fish to 88 $\mathrm{mg} \mathrm{L}^{-1}$ of formalin (tip of the arrow). (D) Proliferation of mucus cells (MC) in exposed fish to $110 \mathrm{mg} \mathrm{L}^{-1}$ (tip of the arrow). (E) Capillary constriction in exposed fish to $88 \mathrm{mg} \mathrm{L}^{-1}$ (tip of the arrow). (F) Hypertrophy of the lamellar epithelium in exposed fish to $110 \mathrm{mgL}^{-1}$ (tip of the arrow). (G) Edema at the concentration in exposed fish to $88 \mathrm{mg} \mathrm{L}^{-1}$ (tip of the arrow). (H) Dilatation of the marginal canal at the concentration in exposed fish to $110 \mathrm{mg} \mathrm{L}^{-1}$ (tip of the arrow). (I) Mucus secretion in exposed fish to $110 \mathrm{mg} \mathrm{L}{ }^{-1}$ (tip of the arrow). (J) Hyperplasia of the lamellar epithelium fish gills exposed fish to 88 $\mathrm{mgL}^{-1}$ (tip of the arrow). (K) Lamellar fusion in exposed fish to $66 \mathrm{mg} \mathrm{L}^{-1}$ (tip of the arrow). (L) Epithelial rupture and hemorrhage in exposed fish to $110 \mathrm{mg} \mathrm{L}^{-1}$ (tip of the arrow). Staining with basic fuchsine and toluidine blue. 


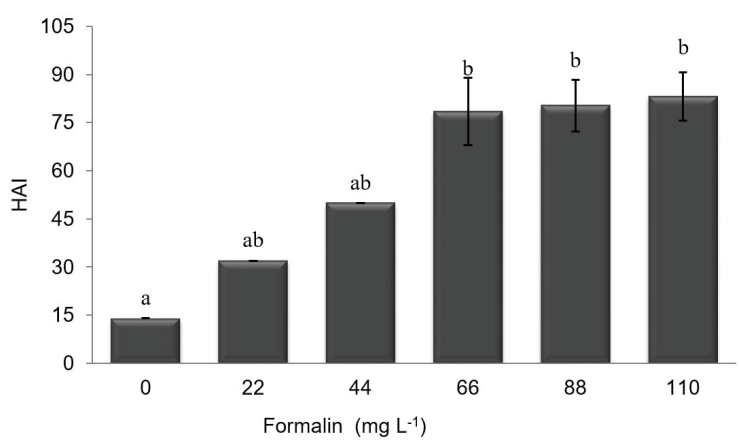

Fig.4. Histopathological alteration index (HAI) of the gills of Arapaima gigas after $96 \mathrm{~h}$ of exposure to different concentrations of formalin. Values are expressed as mean \pm standard deviation. Different letters indicate significant difference by Dunn's test $(\mathrm{p}<0.05)$.

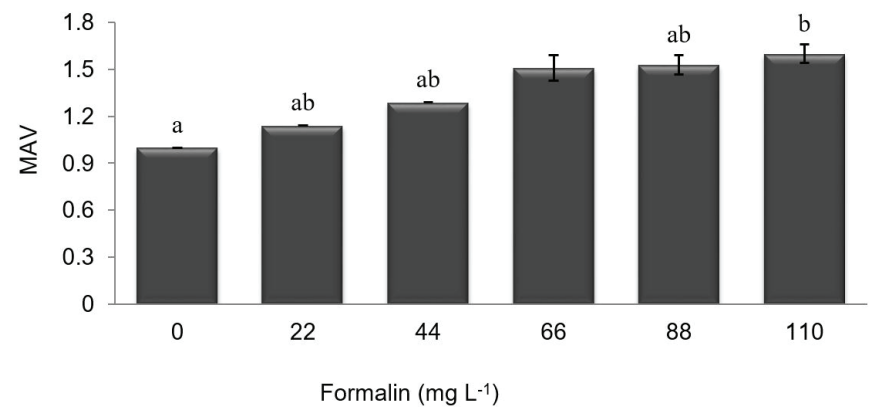

Fig.5. Mean assessment value (MAV) of the gills of Arapaima gigas after $96 \mathrm{~h}$ of exposure to different concentrations of formalin. Values are expressed as mean \pm standard deviation. Different letters indicate significant difference by Dunn's test $(\mathrm{p}<0.05)$.
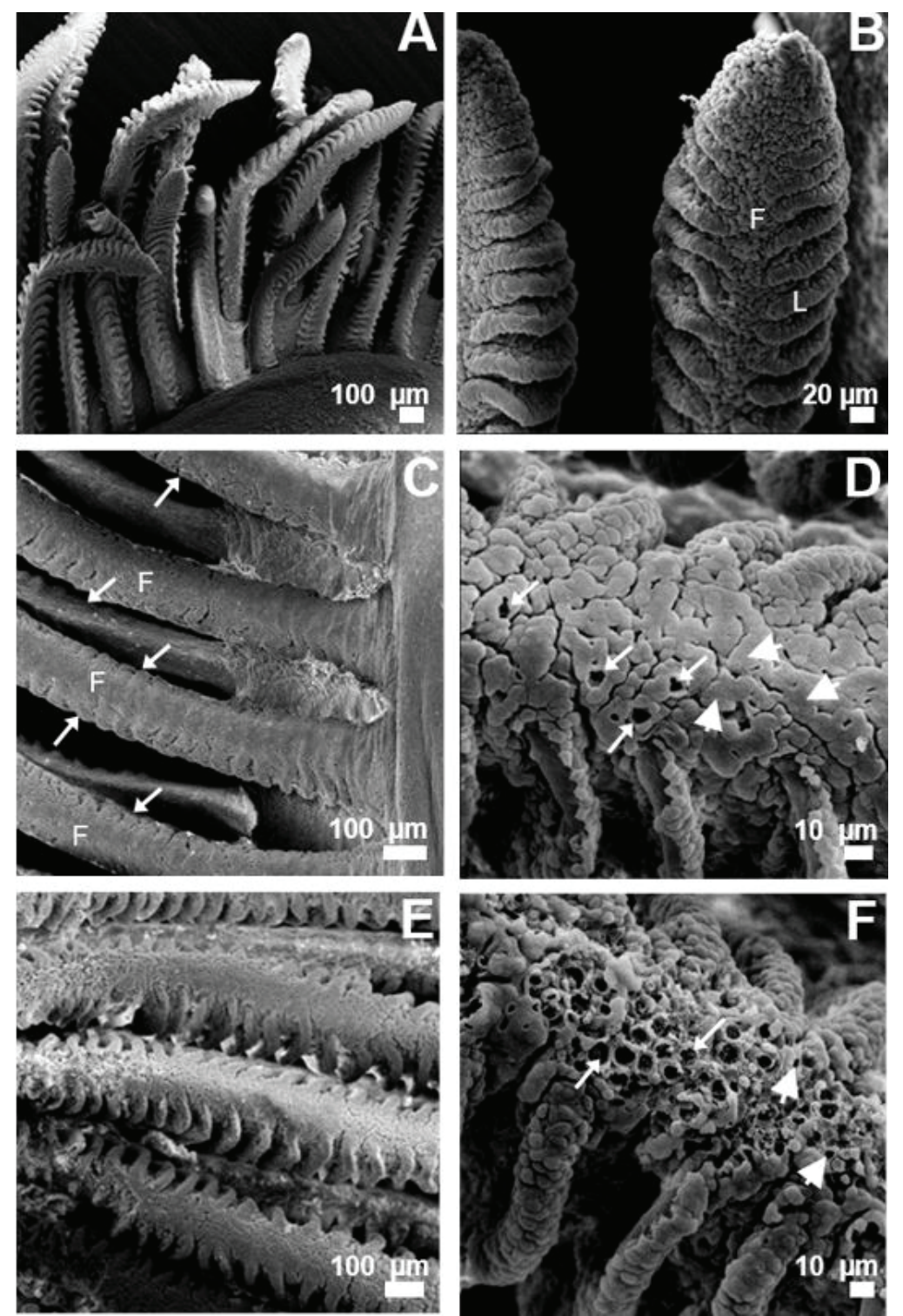

Fig.6. Micrographs using scanning electron microscopy on the gills of Arapaima gigas exposed to different concentrations of formalin. (A) Gill filaments of unexposed fish to formalin with well-defined lamellae. (B) Detail of the gill filament (GF) of unexposed fish to formalin with defined lamellae (L). (C) Gill filaments (GF) of fish exposed to $66 \mathrm{mgL}^{-1}$ of formalin, presenting less evident lamellae (arrows). (D) Detail of the orifices of mitochondria-rich cells (white arrow) and mucous cells (red arrow) on the filaments of fish exposed to 22mgL $\mathrm{m}^{-1}$; (E) Cell proliferation (CP) at the base of filaments of exposed fish to $110 \mathrm{mgL}^{-1}$. (F) Detail of gill filament of exposed fish to $110 \mathrm{mg} \mathrm{L} \mathrm{L}^{-1}$, presenting cell proliferation with an increase in the number of MC (red arrow) and MRC orifices at the base of the filaments (white arrow). 

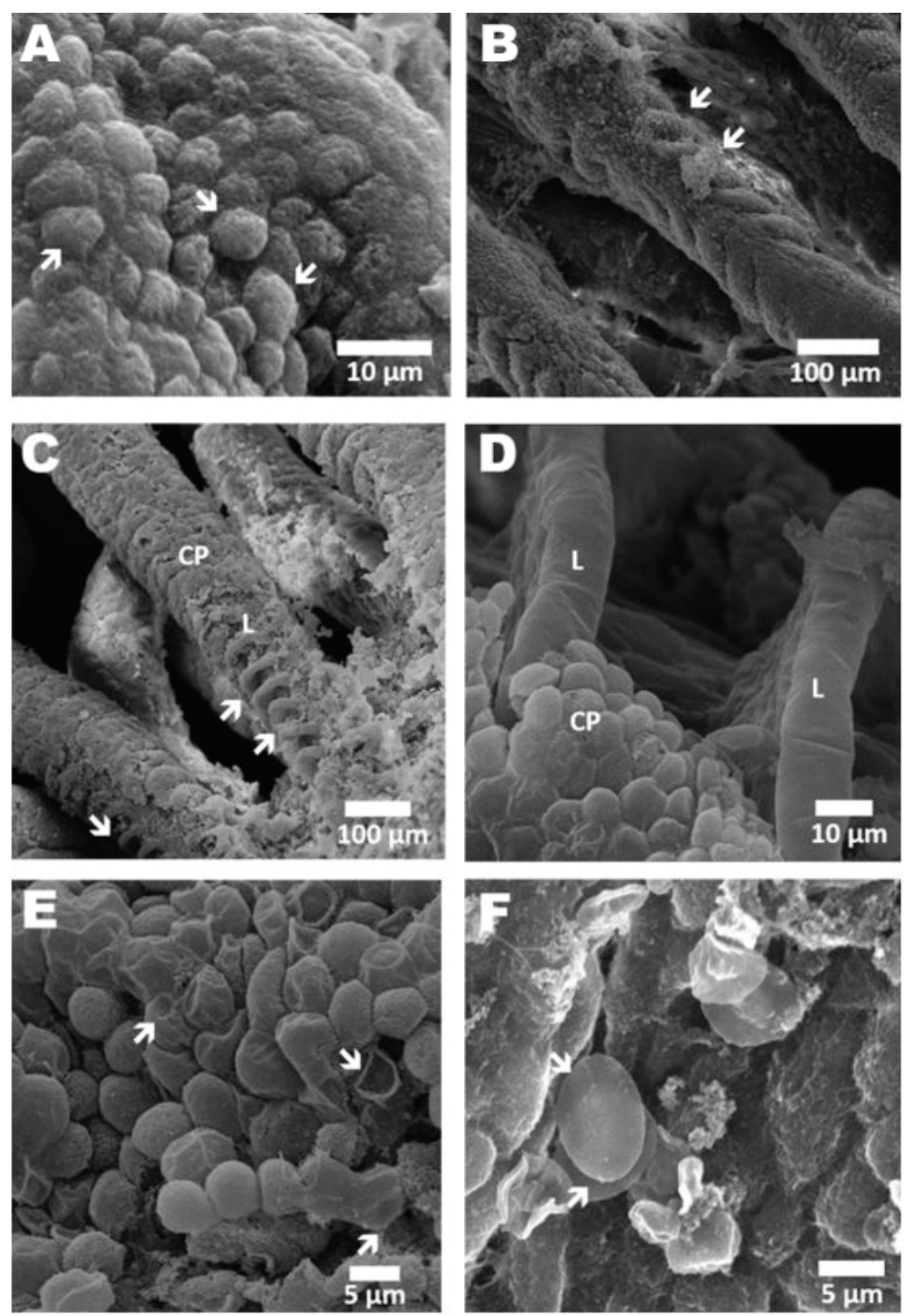

Fig.7. Micrographs from scanning electron microscopy on the gills of Arapaima gigas exposed to different concentrations of formalin. (A) Gill epithelium with pavement cells (white arrows) with convex appearance, and with undefined distribution and cell limit among unexposed fish to formalin). (B) Gill filament of fish exposed to $66 \mathrm{mg} \mathrm{L}^{-1}$, presenting regions with mucous secretion (white arrow). (C) Base region of the filament exposed to $110 \mathrm{mg} \mathrm{L}^{-1}$, with areas of lamellar (L) epithelium detachment (white arrows) and lamellae covered by pavement cells (PC). (D)Detail of the lamella (L) at the base of the filament with absence of pavement cells (white arrows), exposed to $110 \mathrm{mg} \mathrm{L}^{-1}$. (E) Epithelium of a filament exposed to $88 \mathrm{mgL}^{-1}$ with different stages of cell degradation (white arrow). (F) Detail of the gill epithelium of fish exposed to $88 \mathrm{mg} \mathrm{L}^{-1}$ of formalin, presenting hemorrhage (erythrocytes: white arrow)

remained within the acceptable limits for rearing this Amazon fish (Cavero et al. 2004). At high temperatures, formalin may present greater toxicity (Warren 1981). Moreover, Burka et al. (1997) reported that during formalin baths, the water needs a supply of dissolved oxygen, because the addition of this chemotherapeutic product may reduce the availability of $\mathrm{O}_{2}$ in the water. However, during exposure of A. gigas to formalin no change in oxygen levels of water was observed. No change was also reported in the oxygen consumption Salvelinus fontinalis exposure to formalin at 200 and $400 \mu \mathrm{L}^{-1}$ of formalin at low water temperature (Speare et al. 1996). In some conditions such as high concentrations of formaldehyde hydrate and higher temperatures, the dissociation of formalin is favored (Leal et al. 2017).
Exposing fish to a chemical substance is essential for understanding its adverse effects and can be based on mortality rate criteria and complementary analyses, such as on behavioral and histopathological alterations (Perera \& Pathiratne 2005, Leal et al. 2017). The $\mathrm{LC}_{50-96 \mathrm{~h}}$ of $36.4 \mathrm{mg} \mathrm{L}^{-1}$ of formalin among A. gigas juveniles was within the range found for other fish species (Table 6). According to the classification system proposed by Zucker (1985), formalin was considered slightly toxic for A. gigas and, thus it may be used as therapeutic for this species. However, the lethal concentration of this chemotherapeutic substance may vary according to the degree of sensitivity of each fish species and their life cycle stages, considering that fingerlings are more sensitive than juveniles (Table 6). This variation in the sensitivity to formalin among different fish species is also influenced by biological 
Table 6. Lethal concentration ( $\mathrm{LC}_{50-96 \mathrm{~h}}$ ) of formalin for different freshwater fish species

\begin{tabular}{|c|c|c|c|}
\hline Fish species & $\mathrm{LC}_{50-96 \mathrm{~h}}\left(\mathrm{mg} \mathrm{L}^{-1}\right)$ & Stage of life & References \\
\hline \multirow[t]{3}{*}{ Morone saxatilis Walbaum, 1792} & 7.3 & Larva & Wellborn (1969) \\
\hline & 10.0 & Larva & Hughes (1973) \\
\hline & 15.0 & Juvenile & Hughes (1975) \\
\hline Hoplias lacerdae Ribeiro, 1908 & 7.5 & Larva & Cruz et al. (2005) \\
\hline Ictalurus punctatus Rafinesque, 1818 & 14.1 & Fingerling & Howe et al. (1995) \\
\hline Mugil platanus Günther, 1880 & 20.7 & Juvenile & Pahor-Filho et al. (2012) \\
\hline Salvelinus namaycush Walbaum, 1792 & 40.3 & Juvenile & Bills et al. (1977) \\
\hline Oncorhynchus mykiss Walbaum, 1792 & 48.8 & Fingerling & Howeet et al. (1995) \\
\hline Corydoras melanistius Regan, 1912 & 50.7 & Adult & Santos et al. (2012) \\
\hline Micropterus salmoides Lacepéde, 1802 & 54.9 & Fingerling & Bills et al. (1977) \\
\hline Micropterus dolomieu Lacepéde, 1802 & 57.7 & Fingerling & Bills et al. (1977) \\
\hline Arapaima gigas Schinz, 1822 & 36.4 & Juvenile & Present study \\
\hline
\end{tabular}

and physiological factors and by the nutritional state of the fish (Santos et al. 2012), besides time of formalin exposure and its concentration, as well as water quality parameters like temperature (Leal et al. 2017). For instance, A. gigas is an obligatory air-breathing fish that undergoes morphological changes in its gill epithelium during the transition between aquatic respiration and aerial respiration. These morphological alterations during the ontogenetic development of this air-breathing fish may be an innate defense (inflammatory) or compensatory (cell proliferation) mechanism for maintaining physiological homeostasis (Brauner et al. 2004, Ramos et al. 2013), thereby indicating that environmental conditions may have a reversible effect on the gill morphology of this species.

For A. gigas the clinical signs (i.e. corneal opacity, opaque and friable gill, hyperemia with hemorrhage in the caudal peduncle, excess mucous on the skin and gills) and behavioral alterations (i.e. erratic swimming, lethargy, concentration at the water surface of tanks, loss of hydrodynamic balance, spasms, agonistic confrontation) were similar to those described for other fish species with signs of formalin intoxication (Perera \& Pathiratne 2005, Ayuba et al. 2013). However, for A. gigas, behavioral alterations occurred after $13 \mathrm{~h}$ of exposure to formalin, while for fingerling of Poecilia reticulata, moderate swimming, threat of agonistic confrontations and hitting the aquarium walls occurred after only $30 \mathrm{~min}$ of exposure at $6 \mathrm{mg}$ $\mathrm{L}^{-1}$ was reported (Andrade et al. 2005). These results suggest that the concentration/length of exposure relationship directly influences the behavioral patterns of species.

Fish gills are target-organ to unfavorable environment conditions. Biomarkers may be defined as biological responses to exposure to or the toxic effects of an environmental contaminant. Histopathological biomarkers are important responses for diagnosing aquatic ecosystems impacted both by drugs and by pollutants, because it is possible to observe the health and degree of impairment of the tissues in organisms exposed to chemical products (Poleksic \& Mitrovic-Tutundzic 1994, Schwaiger et al. 1997, Santos et al. 2012). The MAV index for $A$. gigas ranged from 1.14 to 1.60 , thus indicating that pathological alterations and gills with separately located lesions were absent (Poleksić \& Mitrovic-Tutundzic 1994, Schwaiger et al. 1997), which did not compromise the functioning of this respiratory organ.

Cell necrosis is an irreversible structural lesion as well as the morphological changes in the A. gigas gill epithelium occurs during the transition from aquatic to air breathing (Brauner et al. 2004, Ramos et al. 2014). On the other hand, hypertrophy and hyperplasia of the lamellar epithelium, proliferation of mitochondria-rich cells (MRCs) and mucus cells (MC), and alterations to blood vessels and development of lamellae in order to optimize gas exchanges and increase the diffusion barrier through proliferation of MRCs are considered reversible histopathological alterations (Poleksić \& Mitrovic-Tutundzic 1994, Sakuragui et al. 2003, Sollid \& Nilsson 2006). Arapaima gigas exposed to different concentrations of formalin did not present irreversible gill lesions even during the exposure to higher concentrations that caused acute toxicity in test of toxicity.

After exposure to formalin, the histopathological alterations found in the present study were classified as reversible lesions, which means that the alterations do not compromise the functioning of the organ (Poleksić \& Mitrovic-Tutundzic 1994, Schwaiger et al. 1997). Moreover, the frequency and severity of the histopathological alterations were directly proportional to the increase in the concentration of formalin, which can be observed through the increasing values of HAI and MAV. Therefore, occur alterations that do not damages the gill tissues to such an extent that an improvement in environmental conditions may lead to reconstruction of this tissue structure, as well as its normal function. However, restoration of the gills structure is not possible when alterations of the third stage occur (Poleksić \& Mitrovic-Tutundzic 1994), but such alterations do not were found in fish of present study.

The gill morphology of $A$. gigas reflects its respiratory mechanisms. As this organ presents distinct changes over the course of its development, such changes particularly involve loss of the lamellae, thereby leaving the organ with the main 
role of ion regulation (Poleksic \& Mitrovic-Tutundzic 1994, Ramos et al. 2013). In fish with body mass similar to that of the specimens used in the present study, the gill morphology is typical of that of a mandatory aquatic breather, such that its lamellar organization and respiratory surface are similar to those of fish with facultative air breathing (Costa et al. 2007). Considering that the species, at this size, presents this type of gill structure, the organ is mainly involved in ion regulatory and respiratory functions. The balance between these functions was named the osmorespiratory compromise by Nilsson (1986). The influence of this balance on A. gigas has probably affected the fish during their development, such that among specimens with a body mass similar to that of the fish in the present study, an increase in the respiratory surface has very little influence on the intake of $\mathrm{O}_{2}$ by the gills, since these fish extract a large portion of this gas through the swimming bladder (Val \& Almeida-Val 1995). However, small fish, with evident lamellae, are influenced by the osmorespiratory compromise, thereby leading to proliferation of MRCs in order to avoid loss of ions (Ramos et al. 2013).

Some xenobiotic substances cause direct effects on gill tissue, but most lesions appear because of defense responses or compensatory mechanisms, thereby representing adaptive strategies for conservation of biological functions when the fish faces natural or human-induced environmental changes (Piedade et al. 2014). The proliferation of MRCs and MCs in A. gigas exposure to formalin represents a compensatory response of this fish aimed at reestablishing the osmotic balance. Thus, the occurrence of lamellar hyperplasia and hypertrophy may represent a defense response in this fish species (Piedade et al. 2014). Histopathological alterations in the lamellar epithelium of the gills of $A$. gigas are likely to be associated with either inflammatory or compensatory defense mechanisms in the presence of the chemotherapeutic substance tested. It is important to note that this fish species presents great tolerance regarding alterations to the osmolytes dissolved in the water, such that Hrbek et al. (2005) considered this to be a panmictic population in the Amazon basin, capable of surviving the abrupt changes found in rivers with white and black waters (Baldisserotto et al. 2008, Ramos et al. 2014). An increase in the number of MRCs leads to alterations to the osmorespiratory compromise, but without damage to the fish's homeostasis. Therefore, these responses here found may have served as a barrier against the entry of contaminants in the blood stream, which could have promoted disorders of homeostasis in the organisms.

An increase in the numbers of mucus cells causes mucus hypersecretion, which has the role of protecting the tissue structure in adverse environmental situations. Mucus, a substance produced by these cells, presents poly anions that can act as a protective barrier against the penetration of xenobiotic substances or pathogens in the respiratory epithelium. Thus, mucus may have a direct influence on osmoregulation through ion availability in the environment (Varsamos et al. 2005, Moron et al. 2009). This substance, which covers the gill epithelium of freshwater fish, also has the function of attracting ions that favor ion exchange, thus presenting high concentrations of $\mathrm{Na}^{+}$and $\mathrm{Cl}^{-}$in relation to the adjacent water (Moron et al. 2009). Therefore, in this case, the role of mucus is to effectively contribute towards the process of ion adjustment and transport, thus aiding in their retention by these fish. Arapaima gigas exposed to different concentrations of formalin also presented proliferation of mucus cells in the gill epithelium, which was frequently found at higher concentrations (88 and $110 \mathrm{mg} \mathrm{L}^{-1}$ ). Moreover, epithelial rupture and aneurisms were lesions found in the gills of fish exposed to these two concentrations, thus indicating occurrences of severe alterations, according to the HAI values (80.3 and 83.2) (Poleksic \& Mitrovic-Tutundzic 1994). Therefore, as expected, the SEM analysis confirmed the structural alterations in the gills of $A$. gigas exposed to different concentrations of formalin.

Finally, safety concentrations of formalin below $36.4 \mathrm{mg} \mathrm{L}^{-1}$ may have efficacy against ectoparasites of $A$. gigas if used in baths of long-term exposure as has been demonstrated for Pterophyllum scalare (Fujimoto et al. 2006) and Parabramis pekinensis (Yao et al. 2011), both freshwater fish.

\section{CONCLUSIONS}

The acute toxicity test demonstrated that formalin is slightly toxic for Arapaima gigas and indicated that fish exposed to prolonged sublethal concentrations $\left(22.0 \mathrm{mg} \mathrm{L}^{-1}\right.$ for 96h) did not present alterations of gill epithelium or of their behavioral patterns.

Lethal concentrations (i.e. $\mathrm{LC}_{50-96 \mathrm{~h}}$ ) should be used with caution and for shorter exposure periods.

HAI and MAV were good indexes for measuring gill structural alterations, thus indicating occurrences of reversible and separately located lesions, which did not compromise gill functioning, and in this manner enabling recovery of the organ after exposure to formalin.

Therefore, these results indicate that in acute exposure bioassay, in addition to evaluation of mortality, histological and behavioral patterns should also be assessed, since they are indispensable tools to investigate sublethal effects of chemotherapeutic products used in aquaculture.

Conflict of interest statement.- The authors hereby declare that there is no conflict of interest in the study.

Acknowledgements.- The authors are grateful to Fundação de Amparo à Pesquisa do Amazonas (FAPEAM) for financial support of this study. M. Tavares-Dias (\#303013/2015-0) was supported by research fellowships from the Conselho Nacional de Desenvolvimento Científico e Tecnológico (CNPq, Brazil), and to Thematic Laboratory of Electronic Microscopy (LTME, INPA) for the help in the scanning electron microscopy analysis.

\section{REFERENCES}

Andrade R.L.B., Andrade L.S., Boscolo W.R. \& Soares C.M. 2005. Comportamento, sobrevivência e desenvolvimento de lebistes, Poecillia reticulata, submetidos a agentes utilizados na profilaxia de doenças. Acta Scient. Anim. Sci. 27:523-528.

Araújo C.S., Gomes A.L., Tavares-Dias M., Andrade S.M.S., Belém-Costa A., Borges J.T., Queiroz M.N. \& Barbosa M. 2009. Parasitic infections in pirarucu fry, Arapaima gigas Schinz, 1822 (Arapaimatidae) kept in a semi-intensivesfish farm Central Amazon, Brazil. Vet. Arch. 79:499-507.

Ayuba V.O., Iyakwari S.P. \& Oyeniyi M.E. 2013. Acute toxicity of formalin on Clarias gariepinus juveniles. Prod. Agricult. Technol. 9:21-28.

Baldisserotto B., Copatti C.E., Gomes L.C., Chagas E.C., Brinn R.P. \& Roubach R. 2008. Net ion fluxes in the facultative air-breather Hoplosternum littorale (tamoata) and the obligate air-breather Arapaima gigas (pirarucu) exposed 
to different Amazonian waters. Fish Physiol. Biochem. 34(4):405-412. http://dx.doi.org/10.1007/s10695-008-9200-y. PMid:18958598.

Bills T.D., Marking L.L. \& Chandler J.H. 1977. Investigation in fish control. Formalin: its toxicity to no target aquatic organisms, persistence, and counteraction. Fish Wildl. Serv. 73:1-7.

Boyd C.E. \& Tucker C.S. 1992. Water Quality and Pond Soil Analyses for Aquaculture. Auburn University, Auburn, USA. 37p.

Brauner C.J., Matey V., Wilson J.M., Bernier N.J. \& Val A.L. 2004. Transition in organ function during the evolution of air breathing, insights from Arapaima gigas, an obligate air-breathing teleost from the Amazon. J. Exp. Biol. 207(Pt 9):1433-1438. http://dx.doi.org/10.1242/jeb.00887. PMid:15037637.

Burka J.F., Hammell K.L., Horsberg T.F., Johnson G.R., Rainnie D.J. \& Speare D.J. 1997. Drugs in salmonid aquaculture. J. Vet. Pharmacol. Ther. 20(5):333349. http://dx.doi.org/10.1046/j.1365-2885.1997.00094.x. PMid:9350253.

Cavero B.A.S., Pereira-Filho M., Bordinhon A.M., Fonseca F.A.L., Ituassú D.R., Roubach R. \& Ono E.A. 2004. Tolerância de juvenis de pirarucu ao aumento da concentração de amônia em ambiente confinado. Pesq. Agropec. Bras. 39(5):513-516. http://dx.doi.org/10.1590/S0100-204X2004000500015.

Cruz C., Fujimoto R.Y., Luz R.K., Portella M.C. \& Martins M.L. 2005. Toxicidade aguda e histopatologia do fígado de larvas de trairão Hoplias lacerdae expostas à solução aquosa de formaldeído a 10\%. Pesticidas, Revta Ecotoxicol. Meio Amb. 15:21-28.

Costa O.T.F., Pedretti A.C.E., Schmitz A., Perry S.F. \& Fernandes M.N. 2007. Stereological estimation of the surface area and barrier thickness of the fish gills in vertical sections. J. Microscopy 255(Pt 1):1-9. http://dx.doi. org/10.1111/j.1365-2818.2007.01710.x. PMid:17286690.

Delgado P.M., Chu-Koo F.W., Malta J.C.O., Gomes A.L.S., Varella A.M.B. \& Martins S.T. 2007. Fauna ectoparasitaria en alevinos de paiche Arapaima gigas (Schiz, 1822) cultivados en el centro de investigaciones de Quistococha, Loreto, Perú. Fol. Amaz. 16:23-27.

Fajer-Ávila E.J., Abdo-de la Parra I., Aguilar-Zarate G., Contreras-Arce R., Zaldívar-Ramírez J. \& Betancourt-Lozano M. 2003. Toxicity of formalin to bullseye puffer fish (Shoeroides annulatus Jenyna, 1843) and its effectiveness to control ectoparasites. Aquaculture 223(1/4):41-50. http://dx.doi. org/10.1016/S0044-8486(03)00166-2.

Farmer B.D., Fuller S.A., Mitchell A.J., Straus D.L. \& Bullard S.A. 2013. Efficacy of bath treatments of formalin and copper sulfate on cultured white bass, Morone chrysops, concurrently infected by Onchocleidus mimus and Ichthyophthirius multifiliis. J. World Aquac. Soc. 44(2):305-310. http:// dx.doi.org/10.1111/jwas.12027.

FDA 2014. Food and Drugs. Food and Drug Administration Department of Health and Human Services, Animal Drugs, Feeds, and related Products certain other Dosage Form of New Animal Drugs: formalin solution. Code of Federal Regulations 21CFR, Part 529.1030.

Fujimoto R.Y., Vendruscolo L., Schalch S.H.C. \& Moraes F.R. 2006. Avaliação de três diferentes métodos para o controle de monogenéticos e Capillaria sp. (Nematoda: Capillariidae), parasitos de acará-bandeira (Pterophyllum scalare Liechtenstein, 1823). Bolm Inst. Pesca 32(2):183-190.

Geiger D.L., Brooke L.T. \& Call D.J. 1990. Acute toxicities of organic chemicals to fathead minnows Pimephales promelas. University of Wisconsin, Madison, Wisconsin. 23p.

Hamilton M.A., Russo R.C. \& Thurston R.V. 1977. Trimmed Spearman-Karber method for estimating median lethal concentration in toxicity biossays. Environm. Sci. Technol. 11(7):714-719. http://dx.doi.org/10.1021/ es60130a004.

Hrbek T., Farias I.P., Crossa M., Sampaio I., Porto J.I.R. \& Meyer A. 2005. Population genetic analysis of Arapaima gigas, one of the largest freshwater fishes of the Amazon basin: Implications for its conservation. Anim. Conserv. 8(3):297-308. http://dx.doi.org/10.1017/S1367943005002210.

Hossler F.E. 1980. Gill arch of the mullet, Mugil cephalus. III. Rate of response to salinity change. Am. J. Physiol. 238(3):R160-R164. PMid:7369390.
Howe G.E., Marking L.L., Bills T.D. \& Schreier T.M. 1995. Efficacy and toxicity of formalin solutions containing paraformaldehyde for fish and egg treatments. Progr. Fish Cult. 57(2):147-152. http://dx.doi.org/10.1577/15488640(1995)057<0147:EATOFS>2.3.C0;2.

Hughes G.M. 1973. Respiratory responses to hypoxia in fish. Am. Zool. 13(2):475-489. http://dx.doi.org/10.1093/icb/13.2.475.

Hughes G.M. 1975. Coughing in the rainbow trout (Salmo gairner) and the influence of pollutants. Rev. Suisse Zool. 82(1):47-64. http://dx.doi. org/10.5962/bhl.part.78257. PMid:1182042.

Kiernan J.A. 1999. Histological and histochemical methods: theory and practice. 3rd ed. Butterworth-Heinemann, Boston. 502p.

Leal J.F., Neves M.G.P.M.S., Santos E.B.H. \& Esteves V.I. 2017. Use of formalin in intensive aquaculture: properties, application and effects on fish and water quality. Rev. Aquacult. https://doi.org/10.1111/raq.12160. (In publication).

Marinho R.G.B., Tavares-Dias M., Dias-Grigório M.K.R., Neves L.R., Yoshioka E.T.O., Boijink C.L. \& Takemoto R.M. 2013. Helminthes and protozoan of farmed pirarucu (Arapaima gigas) in eastern Amazon and host-parasite relationship. Arq. Bras. Med. Vet. Zootec. 65(4):1192-1202. http://dx.doi. org/10.1590/S0102-09352013000400035.

Moron S.E., Andrade C.A. \& Fernandes M.N. 2009. Response of mucous cells of the gills of traíra (Hoplias malabaricus) and jeju (Hoplerythrinus unitaeniatus) (Teleostei: Erythrinidae) to hypo-and hyper-osmotic ion stress. Neotrop. Ichthyol. 7(3):491-498. http://dx.doi.org/10.1590/ S1679-62252009000300017.

Nilsson S. 1986. Control of gill blood flow, p.86-101. In: Nilsson S. \& Holmgren S. (Eds), Fish Physiology: recent advances. Croom Helm, London. http:// dx.doi.org/10.1007/978-94-011-6558-7_5.

Pahor-Filho E., Miranda-Filho K.C. \& Pereira-Júnior J. 2012. Parasitology of juvenile mullet (Mugil liza) and effect of formaldehyde on parasites and host. Aquaculture 354:111-116. http://dx.doi.org/10.1016/j. aquaculture.2012.03.032.

Perera H.A.C. \& Pathiratne A. 2005. Effects of short term exposure to therapeutic levels of formalin on health status of Nile tilapia, Oreochromis niloticus. J. Natl Sci. Found. Lanka 33(4):239-245. http://dx.doi.org/10.4038/jnsfsr. v33i4.2113.

Piedade M.T.F., Almeida e Val V.M.F., Lopes A., Henrique H.S., Fé L.M.L. \& Wittmann F. 2014. Organismos aquáticos e de áreas úmidas em uma Amazônia em transição. Ciênc. Cult. 66(3):34-40. http://dx.doi.org/10.21800/S000967252014000300013.

Poleksic V. \& Mitrovic-Tutundzic V. 1994. Fish gills as a monitor of sublethal and chronic effects of pollution, p.339-352. In: Muller R. \& Lloyd R. (Eds), Sublethal and Chronic Effects of Pollutants on Freshwater Fish. Fishing News Books, Oxford.

Ramos C.A., Fernandes M.N., Costa O.T.F. \& Duncan W.L.P. 2013. Implications for osmorespiratory compromise by anatomical remodeling in the gills of Arapaima gigas. Anat. Rec. 296(10):1664-1675. http://dx.doi.org/10.1002/ ar.22758. PMid:23956000.

Ramos C.A., Raulino J.C.N., Menezes J.C. \& Carmo I.B. 2014. Influences of Amazonian white and black waters on the hematological and biochemical plasma features of Arapaima gigas (Osteoglossiformes). J. Life Sci. 8:252-261.

Sakuragui M.M.J.R., Sanches J.R. \& Fernandes M.N. 2003. Gill chloride cell proliferation and respiratory responses to hypoxia of the Neotropical erythrinid fish Hoplias malabaricus. J. Comp. Physiol. B 173(4):309-317. http://dx.doi.org/10.1007/s00360-003-0337-9. PMid:12677459.

Santos R.F.B., Dias H.M. \& Fujimoto R.Y. 2012. Acute toxicity and histopathology in ornamental fish amazon blue spotted corydora Corydoras melanistius exposed to formalin. An. Acad. Brasi. Ciênc. 84(4):1001-1007. PMid:23207704.

Schlotfeld H.J. 1993. Chemikalienzur therapiebei nutzfischen nun zugelassen! standard-zulassungen. Fischer Teichwirt 12:421-424. 
Schwaiger J., Wanke R., Adam S., Pawert M., Honnen W. \& Triebskorn R. 1997. The use of histopathological indicators to evaluate contaminant-related stress in fish. J. Aquat. Ecosyst. Stress Recov. 6(1):75-86. http://dx.doi. org/10.1023/A:1008212000208.

Silveira M. 1998. Preparo de amostras biológicas para microscopia eletrônica de varredura, p.33-44. In: Souza W. (Ed.), Técnicas Básicas de Microscopia Eletrônica Aplicadas às Ciências Biológicas. Sociedade Brasileira de Microscopia, Rio de Janeiro.

Sollid J. \& Nilsson G.E. 2006. Plasticity of respiratory structures-Adaptive remodeling of fish gills induced by ambient oxygen and temperature. Resp. Physiol. Neurobiol. 154(1/2):241-251. http://dx.doi.org/10.1016/j. resp.2006.02.006. PMid:16540380.

Speare D.J., Goff G., MacIsaac P., Wecherkiwsky J. \& MacNair N. 1996. Effects of formalin and chloramine-T treatments on oxygen consumption of juvenile salmonids. J. Aquat. Anim. Health 8(4):285-291. http://dx.doi. org/10.1577/1548-8667(1996)008<0285:EOFACT>2.3.CO;2.

Val A.L. \& Almeida-Val V.M.F. 1995. Fishes of the Amazon and their Environment: physiological and biochemical aspect. Springer-Verlag, New York. 224p. http://dx.doi.org/10.1007/978-3-642-79229-8.
Varsamos S., Nebel C. \& Charmantier G. 2005. Ontogeny of osmoregulation in postembryonic fish: a review. Comp. Biochem. Physiol. A. 141(4):401429. http://dx.doi.org/10.1016/j.cbpb.2005.01.013. PMid:16140237.

Verdouw H., Van Echteld C.J.A. \& Dekkers E.M.J. 1978. Ammonia determination based on indophenol formation with sodium silicylate. Water Res. 12(6):397402. http://dx.doi.org/10.1016/0043-1354(78)90107-0.

Warren J.W. 1981. Diseases of Hatchery Fish: a fish disease manual. U.S. Fish Wildl. Serv., Reg.3, Twin Cities, MN.

Wellborn Junior T.L. 1969. The toxicity of nine therapeutic and herbicidal compounds to striped. Progr. Fish-Cult. 31(1):27-32. http://dx.doi. org/10.1577/1548-8640(1969)31[27:TTONTA]2.0.CO;2.

Yao J.Y., Li X.L., Shen J.Y., Pan X.Y., Hao G.J., Xu Y., Ying W.L., Ru H.S. \& Liu X.L. 2011. Isolation of bioactive components from Chelidonium majus L. with activity against Trichodina sp. Aquaculture 318(1-2):235-238. http:// dx.doi.org/10.1016/j.aquaculture.2011.04.035.

Zar J.H. 2010. Biostatistical Analysis. 5th ed. Prentice Hall, New Jersey, p.66-361.

Zucker E. 1985. Acute toxicity test for freshwater fish. Standard Evaluation Procedure, Hazard Evaluation Division. USEPA Publication 540:85-106. 